\title{
PENGEMBANGAN LEMBAR KERJA MAHASISWA (LKM) BERBASIS INQUIRI PADA MATA KULIAH STRATEGI PEMBELAJARAN KIMIA
}

\author{
Erviyenni* dan Sri Haryati \\ Program Studi Pendidikan KimiaFKIP Universitas Riau \\ E-mail : erviyenni,@gmaill.com
}

\begin{abstract}
Research of development that held to produce student worksheet (SWS) based on valid inquiry, practice, and effective to complete courses of chemistry learning strategy. The method that used is research of development. The research used consists of four steps, namely define, design, develop, and disseminate, because the limit of time and cost, research just used until to development step. Data of research collected through evaluation sheets filled by validator. Internal validation of SWS describe that SWS writing contain indicators assessment, writing use capital letters, the distance between topic letter with information letter was different, but still used more than 10 words in line. For contain assessment can used by students with various understanding, yet include steps to find, but give various activities (read, discuss, and answer). SWS give opportunities to find different information because instruction that used in exercise requires students to read paper and another book. This activity can develop social and emotional relation, because students werediscuss in their group. Language that used has same with intellectual level of students. Format assessment describe that SWS have a title, purpose, resume, work steps, questions and include reference, also table. It requires students to implement the examples in learning activity.
\end{abstract}

Keywords: development, worksheet, based on inquiry, chemistry learning strategy

\begin{abstract}
Abstrak
Penelitian pengembangan yang dilaksanakan bertujuan menghasilkan lembar kerja mahasiswa (LKM) berbasis inquiri yang valid, praktis dan efektif untuk melengkapi perangkat mata kuliah strategi pembelajaran kimia.Metode penelitian yang digunakan adalah penelitian pengembangan.Penelitian yang dilaksanakan terdiri dari empat tahap, yaitu tahap pendefinisian (define), perancangan (design), pengembangan (develop), pendesiminasian (desseminate), karena keterbatasan waktu dan biayapenelitian hanya sampai pada tahap pengembangan. Data penelitian dikumpulkan melalui lembar penilaian oleh validator. Validasi internal terhadap LKM menggambarkan bahwa penulisan LKM sudah memenuhi indikator penilaian teknis, tulisan menggunakan huruf cetak, antara huruf topik dengan huruf untuk informasi sudah berbeda, tapi masih menggunakan lebih dari 10 kata dalam satu baris. Untuk penilaian Isi dapat digunakan mahasiswa dengan kecepatan bervariasi, belum sepenuhnya memuat langkah untuk menemukan akan tetapi sudah memberikan kegiatan bervariasi (baca, diskusi, menjawab). LKM dapat memberikan kesempatan mencari informasi berbeda karena dalam instruksi mengerjakan latihan, menghendaki mahasiswa untuk membaca makalah dan buku lain, Kegiatan dapat mengembangkan hubungan sosial, emosional karena proses pembelajaran dilakukan secara berkelompok. Bahasa yang digunakan sesuai tingkat intelektual mahasiswa. Penilaian format menggambarkan LKM sudah memilki judul, tujuan, teori singkat, langkah kerja, ada pertanyaan dan sudah mencantumkan daftar pustaka, ada tabel dan menuntut mahasiswa untuk menerapkan contoh-contoh dalam kegiatan pembelajaran.
\end{abstract}

Kata Kunci: pengembangan, lembar kerja, berbasis inquiri,strategi pembelajaran kimia 


\section{PENDAHULUAN}

Perkuliahan yang dilaksanakan di Program Studi Pendidikan Kimia sudah mengacu kepada pembelajaran yang berpusat kepada mahasiswa (Student centered Learning, $S C L$ ), dimana mahasiswa dilibatkan dalam memperoleh dan mengolah informasi serta mempresentasikan materi yang telah dikemas secara berkelompok. Bruner menyatakan bahwa tiga proses berlangsung bersamaan ketika siswa belajar yaitu memperoleh informasi, mentransformasi informasi dan menguji relevansi serta ketepatan pengetahuan. Dosen pengampu mata kuliah telah berupaya melakukan pendekatan, strategi dan model pembelajaran agar mahasiswa dapat mencapai tujuan pembelajaran.

Tim pengampu mata kuliah dalam beberapa tahun terakhir telah berupaya melaksanakan proses perkuliahan dengan melibatkan mahasiswa secara langsung untuk memperoleh berbagai informasi mengenai materi perkuliahan. Mahasiswa ditugaskan membuat makalah dan pada saat tatap muka di kelas telah difasilitasi berupa kesempatan untuk mempresentasikan makalah yang telah dikemas sebelumnyanya sedemikian rupa untuk didiskusikan dalam kelompok maupun dengan kelompok lain. Strategi yang telah diterapkan cukup efektif untuk mengaktifkan mahasiswa, namun dengan alokasi waktu tatap muka selama 2 × 50 menit, menyebabkan mahasiswa tidak dapat berlatih secara maksimal dalam membuat rencana pelaksanaan pembelajaran atau perangkat pembelajaran untuk mata pelajaran kimia di SMA/ MA yang merupakan implementasi dari perkuliahan strategi pembelajaran sebelum dipraktekkan.Mata kuliah Strategi Pembelajaran Kimia merupakan salah satu mata kuliah wajib di program studi pendidikan kimia. Sesuai Alokasi waktu yang ditetapkan, mahasiswa diharapkan dapat memiliki kompetensi seperti memahami karakteristik perkembangan peserta didik yang meliputi aspek kognitif, afektif dan psikomotor, mampu mengimplementasikan dalam bentuk keterampilan profesi kependidikan yang dilandasi teori-teori belajar, pendekatan pembelajaran, metode, model-model dan strategi - strategi pembelajaran aktif lain yang relevan dengan situasi dan kondisi objek peserta didik,maka dipandang perlu untuk mencoba menerapkan salah satu metode pembelajaran yang berpusat kepada mahasiswa yaitu metode pembelajaran inquiri yang berupaya melatih siswa untuk belajar sains mulai dari menemukan masalah sampai menggambarkan kesimpulan tentang masalah (Hofstein, 2005). Untuk melaksanakan metode inkuiri perlu didukung oleh perangkat yang berbasis inkuiri, dalam penelitian ini dititik beratkan untuk LKM .

Menurut Sanjaya (2006) ada beberapa hal yang menjadi ciri utama metode inkuiri yaitu : 1) Inkuiri menekankan kepada aktifitas siswa secara maksimal untuk mencari dan menemukan, artinya model inkuiri menempatkan siswa sebagai subjek belajar. dalam proses pembelajaran, tidak hanya berperan sebagai penerima pelajaran melalui penjelasan guru secara verbal, tetapi 
mereka berperan untuk menemukan sendiri inti dari materi pelajaran itu sendiri. 2) Seluruh aktifitas siswa diarahkan untuk mencari dan menemukan jawaban sendiri dari sesuatu yang dipertanyakan, sehingga diharapkan dapat menumbuhkan sikap percaya diri (Self Convidence). Metode pembelajaran inkuiri dalam hal ini telah berupaya menempatkan guru bukan sebagai subjek belajar, akan tetapi sebagai fasilitator dan motivator belajar bagi siswa. 3) Inkuiri mengembangkan kemampuan berpikir secara sistematis, logis dan kritis, atau mengembangkan kemampuan intelektual sebagai bagian dari proses mental. Dengan demikian, dalam model pembelajaran inkuiri siswa tidak hanya dituntut agar menguasai materi pelajaran, akan tetapi bagaimana mereka dapat menggunakan potensi yang dimilikinya untuk memperoleh pengetahuan dan keterampilan.

Peran guru dalam pembelajaran inkuiri menurut Trianto (2007), terdapat tiga karakter dari metode inkuiri yakni; 1) guru dalam pembelajaran tidak perlu mengkomunikasikan pengetahuan akan tetapi lebih membantu siswa untuk belajar sendiri. 2)cara yang digunakan untuk pemecahan masalah tergantung kepada siswa. 3) pembelajaran dengan pendekatan inkuiri menekankan pada pembelajaran konstruktivisme (Wina Sanjaya, 2008). Untuk dapat menerapkan metode pembelajaran inquiri, dosen pengampu matakuliah akan mencoba merancang LKM berbasisi inquri pada mata kuliah strategi pembelajaran kimia sehingga diakhir perkuliahan mahasiswa diharapkan mampu merancang strategi pembelajaran yang relevan pada mata pelajaran kimia di SMA sederajat. LKM inkuiri dirancang sesuai dengan yang disarankan Banks 1990, yakni mengutamakan tiga tahap seperti investigation berupa kegiatan untuk mengembangkan dalam memproses dan menginterpretasikan informasi, tahap communication ialah kegiatan untuk mengembangkan kecakapan siswa dalam berbagai komunikasi seperti ucapan atau tulisandan tahap participation adalah tahap mengembangkan kecakapandan rasa percaya diri dalam kerja kelompok dan dalam pengambilan keputusan.

Pembelajaran berbasis inkuiri dapat memfasilitasi mahasiswa/siswa untuk belajar menemukan dan tidak hanya menerima ( Heuvelen dalam Wiyanto, 2005). Pembelajaran inkuiri dapat meningkatkan keterampilan pemecahan masalah, kemampuan berfikir kritis. Lawson (2001) menyatakan bahwa seorang guru agar dapat mengajar dengan metode inkuiri harus pernah menerima contoh pembelajaran berbasis inkuiri. Oleh sebab itu LKM yang dirancang berbasis inquiri diharapkan menjadi sarana bagi mahasiswa calon guru menerapkan metode pembelajaran inquiri dalam perkuliahan strategi pembelajaran kimia.

Dalam mengembangkan dan merancang perangkat pembelajaran seperti lembar Kerja Mahasiswa (LKM), tim pengampu mata kuliah telah memfasilitasi mahasiswa untuk dapat belajar dalam proses tatap muka, namun LKM yang dibuat belum efektif dan belum pernah dilakukan validasi oleh pakar, dalam hal ini berarti usaha yang dilakukan tim pengampu mata 
kuliah belum optimal, maka tim dosen merasa perlu melakukan penelitian pengembangan dengan mengacu pada metode penelitian pengembangan yang akan digunakan untuk menghasilkan produk tertentu dan menguji efektifitasnya (Sugiyono, 2008 ). Produk tertentu dalam penelitian pengembangan ini adalah LKM yang disusun yang seharusnya memenuhi syarat-syarat antara lain yakni syarat didaktik, konstruksi dan teknis (Hendro,1992). Sebagaipedoman dalam pengembangan perangkat salah satunya adalah instrument validasi yang akan digunakan validator akan disusun sesuai dengan aspek-aspek menurut ketentuan-ketentuan pelaksanaan validasi yakni meliputi:

1. Relevansi

Apakah cakupan kedalaman, tingkat kesukaran dan kesesuaian langkah penyajian dapat mengembangkan, intelektual, emosional peserta didik yang lamban, sedang maupun yang pandai

2. Keilmiahan

Apakah kegiatan yang menjadi muatan dalam LKM sudah benar, dapat dipertanggungjawabkan dan menekankan pada proses untuk menemukan konsep (memproses infomasi) dan merupakan petunjuk bagi mahasiswa untuk mengembangkan diri.

\section{Fleksibilitas}

Apakah LKM yang dirancang dapat mengakomodasi keragaman mahasiswa sesuai tuntutan masyarakat

\section{Sistematik}

Apakah komponen-komponen dalam LKM menunjang ketercapaian kompetensi, mahasiswa melakukan kegiatan yang bervariasi seperti menulis, menggambar, bertanya (comucation, participation) kepada teman dan menggunakan alat.

5. Mengikuti azas-azas pembelajaran yang efektif yaitu pengalaman belajarnya ditentukan oleh tujuan pengembangan pribadi mahasiswa bukan ditentukan oleh materi pembelajaran

Pengembangan yang telah dilakukan pada penelitian ini hanya sampai kepada tahap pengembangan produk awal (Develop preliminary form of product), karena keterbatasan waktu dan biaya. Langkah penelitian ini mengacu pada strategi yang dikembangkan oleh Borg and Gall (2010) yang disebut sebagai siklus R ( Reaserch) \& D ( Development) yang terdiri dari mempelajari temuan penelitian yang berkaitan dengan produk yang akan dikembangkan, mengembangkan produk berdasarkan temuan, melakukan pengujian terhadap produk yang dikembangkan, merevisi untuk memperbaiki kekurangan yang ditemukan.

Penelitian bertujuan untuk mengembangkan perangkat pembelajaran berupa Lembar Kerja mahasiswa (LKM) untuk mata kuliah Strategi Pembelajaran Kimia berupa prototipe LKM yang praktis dan valid yang telah divalidasi internal maupun 
eksternal dan siap untuk diujicoba. Penelitian pengembangan bertujuan untuk menghasilkan produk perangkat pembelajaran pada mata kuliah strategi pembelajaran kimia berupa LKM yang valid dan praktis yang siap untuk diujicobakan kepada mahasiswa kimia FKIP.

\section{METODE PENELITIAN}

Metode yang akan dipedomani dalam penelitian pengembangan mengacu kepada metode penelitian pengembangan ( Sugiyono, 2008 ; Borg and Gall, 2010) yang bertujuan untuk mengembangkan dan menghasilkan prototipe perangkat pembelajaran berupa LKM mata kuliah strategi pembelajaran kimia yang valid, praktis dan siap untuk diujicoba dan diimplementasikan dalam perkuliahan.

Pembuatan dan pengembangan LKM didasarkan pada silabus materi ajar dan metode pembelajaran berbasis inquiri yang akan diterapkan oleh tim pengampu mata kuliah strategi pembelajaran kimia. Dilakukan pemilihan dan pemilahan materi ajar yang dipandang lebih membutuhkan sumber belajar /media berupa LKM. Perancangan LKM dirinci untuk digunakan dalam satu semester tatap muka. LKM berbasis inquiri yang akan dirancangmempedomani syarat didaktik, isi dan konstruksi. Rancangan LKM akan divalidasi oleh validator menggunakan lembar validasi yang sudah dirancang peneliti. Validator terdiri dari tim pengampu mata kuliah dan teman sejawat lain. Hasil validasi akan direvisi sesuai saran, masukan dan perbaikan dari validator. Kategori hasil penilaian validator dapat dilihat pada Tabel 1.

Tabel 1. Kategori Validasi LKM berbasisi Inquiri dan Validasi Materi

\begin{tabular}{ccc}
\hline Skala Nilai & Skor & Tingkat Validasi \\
\hline 5 & $64-75$ & Sangat Baik \\
\hline 4 & $52-63$ & Baik \\
\hline 3 & $40-51$ & Sedang \\
\hline 2 & $28-39$ & Tidak Baik \\
\hline 1 & $15-27$ & Sangat Tidak Baik \\
\hline
\end{tabular}

Untuk menghitung persentase skor setiap validasi digunakan rumus sebagai berikut:

Persentase skor : $\frac{\text { jumlah skor }}{\text { jumlah skor maksimum }} \times 100 \%$

Untuk keperluan pengambilan keputusan mengenai layak tidaknya produk 
pengembangan ini, maka digunakan kriteria pengambilan keputusan pada Tabel 2.

Tabel 2. Kriteria Kualifikasi Produk LKM Inquiri

\begin{tabular}{ccl}
\hline Skor & Tingkat Pencapaian & \multicolumn{1}{c}{ Kualifikasi } \\
\hline 5 & $81 \%-100 \%$ & Sangat Baik/Sangat Layak/Sangat Efektif \\
\hline 4 & $61 \%-80 \%$ & Baik/Layak/Efektif \\
\hline 3 & $41 \%-60 \%$ & Cukup Baik/Cukup Layak/Cukup Efektif \\
\hline 2 & $21 \%-40 \%$ & Kurang Baik/Kurang Layak/Kurang Efektif \\
\hline 1 & $0 \%-20 \%$ & Sangat Tidak Baik/Sangat Tidak Layak/Sangat Tidak Efektif \\
\hline
\end{tabular}

(Akbar, 2013)

Pada penelitian pengembangan perangkat sesuai waktu dan dana yang tersedia maka telah dihasilkan empat set LKM berbasis inquiri untuk empat kali tatap muka efektif.

\section{HASIL DAN PEMBAHASAN}

Penelitian yang telah dilaksanakan di program studi pendidikan kimia Jurusan PMIPA FKIP Universitas Riau dimulai pada bulan Juli sampai Desember 2013. Tahap awal Tim peneliti mengumpulkan bahan/literatur sebagai pedoman pembuatan draf LKM Inquiri dan validasi oleh validator dari teman sejawat telah dilakukan, Hasil validasi berupa penilaian terhadap isi dengan nilai rata-rata 3,65, rata-rata penilaian format 3,70 dan teknis penulisan LKM yang dihasilkan memperoleh nilai rata-rata 3,75. Rata keseluruhan dari ketiga syarat perancangan LKM adalah 3,70 dengan kategori baik

Hasil penilaian Lembar Kerja Mahasiswa (LKM) oleh validator menggambarkan bahwa penulisan LKM sudah memenuhi standar indikator penilaian teknis dimana tulisan yang dimuat pada LKM sudah menggunakan huruf cetak, sudah membedakan antara huruf yang dugunakan untuk topik dengan penulisan huruf pada bahagian informasi, dalam pengungkapan kalimatnya masih ada yang menggunakan lebih dari 10 kata untuk satu baris, walau sudah direvisi dengan menggunakan kalimat-kalimat yang hanya bertuliskan informasi -informasi yang dianggap sangat penting, pertanyaan-pertanyaan yang diajukan telah bersifat lebih menggiring mahasiswa untuk menemukan jawaban-jawaban dari permasalahan yang diajukan.Dalam artian pada proses pembelajaran mahasiswa telah diarahkan untuk memperoleh jawaban permasalahan secara mandiri bukan diberikan jawaban oleh dosen pengampu.

Untuk penilaian Isi dari LKM hasil pengembangan sudah memberikan indikasi bahwa dapat digunakan mahasiswa dengan kecepatan yang bervariasi dan dalam arahan kegiatannya sudah memberikan kegiatan bervariasi yang lebih menuntut mahasiswa untuk terlibat aktif dengan kegiatan yang bervariasi seperti mahasiswa diberi kesempatan membaca buku sumber, berdiskusi dengan teman kelompok dan menjawab permasalahan yang ada pada lembar kerja, hal ini sesuai dengan yang dikemukakan Banks1990 bahwa aktivitas dalam inkuiri menghendaki 
adanya pengolahan informasi, rasa percaya diri untuk berkomunikasi dan bertanya dalam kelompok

Hasil penilaian terhadap format,LKM yang didesain peneliti sudah memilki judul sesuai materi, mencantumkan tujuan pembelajaran yang akan dicapai pada setiap LKM, sudah memuat teori singkat yang berkaitan dengan permasalahan yang bertujuan memudahkan mengarahkan mahasiswa, memberikan petunjuk/ langkah kerja, sudah memuat pertanyaan-pertanyaan yang relevan dengan materi dan tujuan pembelajaran, sudah menunjukkan sumber bacaan /memuat daftar pustaka yang dapat membantu mahasiswa untuk melengkapi sumber belajar dalam proses pembelajaran, sudah ada tabel yang memudahkan mahasiswa dan menuntut mahasiswa untuk menerapkan contoh-contoh dalam kegiatan pembelajaran., hal ini didukung oleh Trianto 2007 bahwa cara yang digunakan siswa/ mahasiswa dalam memecahkan masalah tergantung kepada cara dan keinginan mereka sendiri.

LKM berbasis inquiri yang dihasilkan diharapkan dapat memberi kesempatan luas kepada mahasiswa untuk mencari informasi yang berbeda karena dalam instruksi pengerjaan latihan meminta mahasiswa untuk membaca makalah dan buku sumber belajar lain jika dipandang perlu, sesuai dengan yang dikemukakan Sanjaya (2006) bahwa aktifitas siswa diarahkan untuk mencari dan menemukan jawaban sendiri dari sesuatu yang dipertanyakan, sehingga diharapkan dapat menumbuhkan sikap percaya diri (Self Convidence) siswa itu sendiri.

Metode pembelajaran inkuiri yang diaplikasikan dalam perancangan LKM telah menempatkan guru bukan sebagai subjek belajar, akan tetapi sebagai fasilitator dan motivator dalam belajar. Kegiatan yang dirancang dalam LKM dapat mengembangkan hubungan sosial emosional antar mahasiswakarena proses pembelajaran yang dirancang harus dilakukan mahasiswa secara berkelompok. Bahasa yang digunakan dalam penulisan LKM mudah dimengerti dan sesuai tingkat intelektual mahasiswa.

Kalimat sederhana dan jelas yang dapat memudahkan mahasiswa dalam pemecahan masalah. Tata urutan materi sudah sesuai tatanan kurikulum/ silabus mata kuliah strategi pembelajaran, dimulai dari yang mudah Pertanyaan-pertanyaan yang disusun pada LKM telah disusun untuk dijawab dengan pengolahan informasi, sumber belajar terjangkau oleh mahasiswa karena materi yang dibutuhkan untuk penyelesaian LKM berupa buku, internet. Pada LKM tersedia kolom yang cukup untuk menuliskan jawabanyang bertujuan memudahkan mahasiswa mengerjakan dan menyimpan materi perkuliahan 


\section{KESIMPULAN}

Produk LKM inquiri yang dihasilkan untuk mata kuliah strategi pembelajaran kimia telah memenuhi syarat menurut penilaian validator dengan kategori baik. Berarti LKM yang telah dihasilkan dapat diujcobakan kepada mahasiswa Pendidikan Kimia FKIP yang mengambil mata kuliah strategi pembelajaran kimia pada semester yang akan datang. Untuk dapat melihat keefektifan dan pengaruh penggunaan LKM terhadap prestasi belajar pada mata kuliah strategi pembelajaran kimia.

\section{DAFTAR PUSTAKA}

Akbar, Sa'adun. 2013. Instrumen Perangkat Pembelajaran. Bandung: Rosda.

Anonim, 2013 Buku Pedoman Fakultas Keguruan Ilmu Pendidikan, Unri Pres

Pekanbaru

Asnawir, 2003, Media Pembelajaran, Rineka Cipta, Jakarta

Borg,W.R and Gall. M.D. 2010. Applying Educational Research. New York. Longman. Pearson

Erviyenni dan Sri Haryati, 2012.Perangkat pembelajaran Strategi Pembelajaran Kimia.Program studi Pendidikan Kimia.Riau.Laporan .

Hendro Darmojo dan Jerry RE, Kaligis 1992, Pendidikan IPA II, Depdikbud, Jakarta.

Hofstein.W, 2005.Developing student's ability to ask more and better question resulting inqury type chemistry laboratories.Jounal of science teaching.42 (7). $791-806$

Lawson, A, E. 2001. Science Teaching And Development Of Thinking. California. Wadsworth Company

M. Nur, 2004, Buku Panduan Keterampilan Proses dan Hakikat Sains, Univercity Press Surabaya

M. Uzer Usman, 2006, Menjadi Guru Profesional, PT Remaja Rosda Karya, Bandung

M. Nur dan Kardi, 2000, Pengantar Pada Pengajaran dan Pengelolaan Kelas, Univercity Press Surabaya

Mulyasa, 2007, Menjadi Guru Profesional: Menciptakan Pembelajaran Kreatif dan Menyenangkan: Remaja Rosda Karya, Bandung

Sanjaya (2006).Strategi Pembelajaran. Kencana Prenada Media Bandung

Suhadi. I, 2006, Menyikapi KTSP Tantangan Untuk Penyelenggaraan Pembelajaran yang Lebih Baik. Jurnal Pendidikan Inovatif Vol 2 hal 236-242

Trianto (2007). Model-model Pembelajaran Inovatif Berorientasi kontruktivisme.

Prestasi Pustaka Publisher. Jakarta

Wina Sanjaya 2008,Pembelajaran Dalam Inovasi KBK, Kecana Pramedia Grouop, Jakarta

Wiyanto. 2005. Pengembangan kemampuan merancang dan Melaksanakan Kegiatan Laboratorium Fisika Berbasis Inkuiri Bagi siswa Calon Guru, Rangkuman Disertasi. PPS-UPI, Bandung 